\title{
The Politics of Caring in a Bilingual Classroom: A Case Study on the (Im)possibilities of Critical Care in an Assimilationist School Context
}

Charise Pimentel

Follow this and additional works at: https://digitalscholarship.unlv.edu/jpme

\section{Repository Citation}

Pimentel, Charise (2011) "The Politics of Caring in a Bilingual Classroom: A Case Study on the (Im)possibilities of Critical Care in an Assimilationist School Context," Journal of Praxis in Multicultural Education: Vol. 6: No. 1, Article 7.

DOI: 10.9741/2161-2978.1053

Available at: https://digitalscholarship.unlv.edu/jpme/vol6/iss1/7

This Article is protected by copyright and/or related rights. It has been brought to you by Digital Scholarship@UNLV with permission from the rights-holder(s). You are free to use this Article in any way that is permitted by the copyright and related rights legislation that applies to your use. For other uses you need to obtain permission from the rights-holder(s) directly, unless additional rights are indicated by a Creative Commons license in the record and/ or on the work itself.

This Article has been accepted for inclusion in Journal of Praxis in Multicultural Education by an authorized administrator of Digital Scholarship@UNLV. For more information, please contact digitalscholarship@unlv.edu. 


\section{The Politics of Caring in a Bilingual Classroom: A Case Study on the (Im)possibilities of Critical Care in an Assimilationist School Context}

\section{Charise Pimentel}

By juxtaposing colorblind and critical approaches to caring, the author suggests there is often a disjuncture between teachers' caring practices and those that students of color and/or language minorities may expect of their teachers. While critical care may provide the foundation for equitable practices, the author warns against idealizing critical care. The author makes a case that all classroom practices, including pedagogies of care, must be contextualized in larger social and political power dynamics that often shape the im(possibilities) of caring. The article includes a case study of a fourth and fifth grade dual language bilingual teacher, wherein the author examines what critical care practices the teacher is able to enact within the context of a deficit-oriented and assimilationist school setting.

Trabajo muy duro cada día. Hago todo que yo puedo para crear una clase adonde mis estudiantes que hablan español pueden brillar. Pero despues de todo que he hecho, no pienso que hago una diferencia. Por eso, no pienso que soy un buen maestro.

I work hard every day. I do everything I can to create a classroom in which my students who speak Spanish can shine. But after everything that I have done, I do not think that I make a big difference. For this reason, I do not think I am a good teacher.

Mr. Potts

Viewpoint Elementary School

In all practical senses, Mr. Potts embodies many idealized qualities of a critical caring, multicultural, and bilingual teacher. He works long hours to collaborate with students and their parents to develop innovative curricular and pedagogical practices that affirm and build upon his Latina/o students' home languages and cultures and regularly tries to interrupt and transform the assimilationist and deficit discourses that shape school policies and practices at Viewpoint Elementary. Ironically however, despite Mr. Potts' attempts to critically care for and thereby carve out equitable educational experiences for the Latina/o students in his class, Mr. Potts is often left unsatisfied with the

Dr. Charise Pimentel is an Assistant Professor in the Department of Curriculum and Instruction at Texas State University- San Marcos. Her research centers on Race and Education, Bilingual Education, Multicultural Education, and Critical Whiteness Studies. 
outcomes of his pedagogical practices, and in extension, unsatisfied with himself as a teacher.

In this article, I examine the complexities of Mr. Potts' critical care practices. Drawing from a case study on Mr. Potts' bilingual classroom, I analyze the (im)possibilities of critical care within the context of a deficitoriented and assimilationist school setting. Within this case study, I argue that the outcomes of Mr. Potts' critical care practices should not be attributed to his intentions or practices alone - as seems to be reflected in his own assessment of himself as a teacher - but must be understood in light of the larger contextual influences on those practices. Thus, this article contributes to the critical care research by examining what critical care practices might look like in a bilingual classroom that is embedded in an otherwise assimilationist and English-only schooling context.

\section{The Ethic of Care in Educational Contexts}

Most teachers claim they care for the kids they teach, regardless of their students' racial, cultural, socio-economic, and linguistic backgrounds. Indeed, many teachers identify the ethic of care as the reason why they went into the teaching profession - they care about kids! Likewise, many researchers have identified the ethic of care, or the caring relationship between student and teacher, as a central component to students' academic achievement. Recently, this research has focused on the importance of caring relationships in the academic success of Latina/o students in the U.S. (Antrop-González \& De Jesús, 2006; De Jesús \& Antrop-González, Nieto, 2008; Rolón-Dow, 2005; Valenzuela, 1999). Considering that Latina/o students have been traditionally underserved in U.S. schools, the quality of the caring relationships teachers have with their Latina/o students may hold some promise in improving the educational experiences educators offer Latina/o youth.

Research demonstrates, however, that the types of caring relationships most teachers engage in with their Latina/o students is counterproductive to the goals associated with school equity. That is, even when teachers think fondly about their Latina/o students and may care about how Latina/o students perform academically, many researchers find that teachers' caring intentions may be misdirected, insufficient, and in many cases, perpetuate inequitable schooling practices, and thus Latina/o school failure (Antrop-González \& De Jesús, 2006; De Jesús \& Antrop-González, Nieto, 2008; Rolón-Dow, 2005; Valenzuela, 1999). Indeed, as the literature on educational care and Latina/o students reflects, there is often a disjuncture between the caring practices teachers offer their students and the caring practices sought out by Latina/o youth. In pointing out this disjuncture, Valenzuela (1999) makes an important distinction in stating that teachers' caring practices are often invested in the "schooling" of Latina/o 
youth, and not the "education" of Latina/o youth. The schooling of Latina/o students is bound to institutional notions of success, including how well students perform on pre-determined, state-mandated curricula and standardized tests. This instrumental or results-driven approach to caring, also referred to as aesthetic caring (Valenzuela, 1999), often subtracts cultural and linguistic resources from students in the pursuit of academic achievement. According to Valenzuela, when teachers approach the caring relationship with their students in these apolitical, colorblind terms, students learn that major aspects of their lives have no relevancy in the school setting. Thus, despite teachers' best intentions to care, many students are left feeling as though their teachers do not care, and this approach to caring, as Valenzuela (1999) states, leaves Latina/o students "progressively vulnerable to academic failure" (p. 3).

Critical approaches to caring, in contrast to colorblind and/or aesthetic approaches to caring, are grounded in a political, color-conscious, and culturally relevant perspective that is concerned about the well-being and education of the whole child - not just school-sanctioned criteria for academic achievement. Thus, a critical approach to caring affirms and nurtures students' cultural and linguistic qualities and often resembles the caring relationships Latina/o students have experienced in their homes. Valenzuela's (1999) work with Mexican students at Seguín High School, for example, demonstrates that students seek an authentic caring relationship with their teachers - one that is grounded in Mexican cultural understandings of educacion. In contrast to schooling, Valenzuela defines educación as, "the family's role of inculcating in children a sense of moral, social, and personal responsibility and... a competence in the social world, wherein one respects the dignity and individuality of others" (p. 23). De Jesús and Antrop-González (2006) and Antrop-González and De Jesús (2006) similarly argue that critical caring relationships within the schools they studied (El Puente and PACHS) often mirror the cultural practices of the Latino communities that created these schools, including cultural constructs such as personalismo (characterized as high-quality interpersonal relationships), and the Puerto-Rican notion of "hard caring" (the high expectation of academic excellence, coupled with follow-through and consequences for low performance).

In addition to reflecting students' cultural practices such as educacion and personalismo, a critical approach to caring also involves a critical literacya way of reading the world that is attentive to the everyday production of social inequities. In Rolón-Dow's (2005) articulation of a color(full) critical care, she argues that teachers must "care enough to understand how such issues as white privilege and racism, colonization, migration, and citizenship have played out in the communities where they teach and have affected the education of Latino/a students" (p. 104). In this respect, critical care is not colorblind or powerblind, but rather is attuned to the reality that students of color need to build a sense of 
resiliency, resistance, and even protest in order to be successful in a social context that often does not recognize their strengths (O'Conner, 1997; Thompson, 1998).

As I move into Mr. Potts' case study, I must clarify that Mr. Potts' difficulty to enact equitable outcomes for his Latina/o students does not emerge from a colorblind, aesthetic approach to caring. Rather, Mr. Potts' difficulty arises from the contextual factors that constrain Mr. Potts' attempts to engage in critical care practices. By building upon the research on critical care, this article makes the case that implementing critical care practices in assimilationist and deficit-oriented school contexts is not a straightforward process. As De Jesús and Antrop-González (2006) state, “...mediating the tensions between aesthetic and authentic caring is related to school structures that emphasize or delimit particular forms of teacher caring" (p. 284). The research in this article examines the (im)possibilities of critical caring in Mr. Potts' two-way dual language bilingual classroom.

\section{Methodology}

Data for this article derive from an ethnographic study in Mr. Potts' bilingual classroom, wherein I take a case study approach to examine Mr. Potts' multicultural practices. Within this two-year study, I carried out participantobservations, formal interviews, and informal discussions that centered on the successes, as well as the difficulties, in carrying out a multicultural agenda in his classroom. The purpose of this engaged methodology was to gain an in-depth understanding of the factors that either impede or facilitate Mr. Potts' local attempts to implement multicultural education. The data was coded using a constant comparative method (Strauss, 1996), from which the ethic of care emerged as a theme from the data. During data collection, the idea that all teachers at Viewpoint Elementary cared about their Latina/o students emerged many times, although teachers' approaches to caring differed greatly. Within this case study, I analyze Mr. Potts' approach to caring, which I have identified as within the critical approach to caring, and examine how his critical care practices are shaped by the assimilationist school context in which he works.

\section{Viewpoint Elementary}

Viewpoint Elementary is located in the Western United States in a large metropolitan area, and is situated on the west side of the city, where a majority of the city's Latina/o, as well as other ethnic populations, reside. Viewpoint Elementary had 720 students at the time of this study. Of these 720 students, 
$73 \%$ qualified for free or reduced-cost lunches, and nearly $60 \%$ of the student body was Latino and learning English as their second language.

Despite the large Latino and bilingual population that attend Viewpoint Elementary, the school is largely driven by monocultural and monolingual teaching orientations. There is no comprehensive bilingual program at this school and most teachers believe students come to school with a disadvantage when they speak a language other than English. For the most part, the administration and most of the teachers believe Latina/o, Spanish-speaking students should learn English as quickly as possible, and the best way to do this is to mainstream them into English-instructed classrooms.

\section{Mr. Potts}

Mr. Potts is a 35-year-old white man, who has been teaching elementary school for 10 years in various models of bilingual education. Mr. Potts became fluent in Spanish when his family moved to Chile when he was 9 years old. In Chile, Mr. Potts occupied the identities of language and ethnic minority, and went through an experience wherein the knowledge he held, and that could be expressed in English, was rendered non-existent in a school system that operated solely in Spanish. After an initial assessment, Mr. Potts was placed in a grade level below what he had already completed in the United States and was demoralized in a number of other ways, including the changing of his name. Because of Mr. Potts' experiences as a child, he became attuned to the ways in which language politics can work to disengage and cut off students' opportunities for school success. He knew that language minorities in the United States often experience what he experienced as a child: the systematic invalidation of students' knowledge and worth. As a result of Mr. Potts' critical awareness and knowledge on language politics in educational settings, Mr. Potts has become an advocate for providing equitable educational opportunities to language minority students. At the time of the study, Mr. Potts was teaching a fourth and fifth grade two-way dual language immersion bilingual class in English and Spanish.

\section{Critical Caring Through Bilingual Education}

As discussed previously, the critical approach to caring emphasizes the need to value the whole student, including the language(s) they speak. With this in mind, schools that critically "care" about students implement pedagogical and curricular practices that not only acknowledge the wealth of knowledge bilingual students bring to their schooling experiences but also facilitate a learning style that builds upon and further develops this knowledge. Being bilingual himself, Mr. Potts recognizes the benefits of being bilingual and firmly 
believes that students can learn a school's curriculum in any language, not just the English language.

Mr. Potts is also cognizant of how the colorblind and assimilationist approaches to caring that were in place at Viewpoint Elementary (e.g., mainstreaming) devalued students' culture and language and put them at a disadvantage for learning the curriculum because they did not understand the language of instruction. In an attempt to counteract these deficit-oriented practices, and in turn validate students' languages, Mr. Potts decided to implement a stand-alone, two-way dual language bilingual classroom. As much as he could, Mr. Potts attempted to mirror a 50/50 dual language model in his classroom. He had an integrated classroom of Spanish dominant and English dominant students, he aimed to deliver his instruction equally in both languages, and both languages, as well as bilingualism, were perceived as valid academic content and goals all students worked toward. Mr. Potts intentionally chose the two-way dual language model to implement in his classroom, because his teaching experience in other bilingual models (transitional and one-way) proved to position Spanish-speaking students deficiently, despite their being in a bilingual program. According to Mr. Potts, only the two-way dual language bilingual model held the potential to counteract the deficit perceptions the Latina/o, Spanish-dominant students otherwise occupied at Viewpoint Elementary.

The central point in this article is that the (im)possibilities of critical care must be understood within the specific context in which they take place. In what follows, I examine the complexities of Mr. Potts' critical care practices, paying particular attention to the ways his critical care practices are constrained within an assimilationist and deficit-oriented schooling context. In the next section on placement strategies, I demonstrate how an assimilationist school setting informed distinct placement strategies that were used in Mr. Potts' class, which ultimately affected the outcomes of Mr. Potts' caring intentions and practices.

\section{Placement Strategies}

Despite Mr. Potts' attempts to implement a critical caring approach through his dual language classroom, the outcomes were not always aligned with his intentions to critically care for his Latina/o students. Because the teaching staff at Viewpoint Elementary believed that English-only instruction would ultimately lead to Latina/o, Spanish-speaking students' success in school, they saw Mr. Potts' class as a waste of time, both for the Latina/o, Spanish-speaking students, as well as for the white, English-speaking students enrolled in his class. Many teachers saw Mr. Potts' class as time off task - that is - students waste time learning Spanish in Mr. Potts' class - time that should be used 
learning English. This logic applied to the white, English-dominant students as well, especially those who were reading either at or below grade level in English. These teachers reasoned that these white, English-dominant students were better off spending their time developing their reading and writing skills in English, rather than learning a second language and thereby risking falling even further behind in their English literacy skills.

As a result of teachers' viewpoints of Mr. Potts' bilingual classroom, the teachers often strategically intervened in the placement decisions for $\mathrm{Mr}$. Potts' class. In essence, the Latina/o, Spanish-speaking students who were placed in Mr. Potts' class were those students who teachers identified as being the furthest behind - often those students who they were not able to reach because of the language barrier. These students were identified by some kind of academic or social deficiency in the mainstream classroom that was thought to be better addressed in a classroom environment in which their language was being spoken. On the other hand, the white, English-dominant students who were placed in Mr. Potts' class were those defined as gifted students - those who were reading above grade level, and thought to be able to handle the rigor of learning a second language without jeopardizing their already achieved English language literacy skills. As a result, the students in Mr. Potts' classroom consisted of a mix of students perceived as either academically inferior Latina/o, Spanish-speaking students or academically superior white, English-speaking students. In this context, Mr. Potts' attempt to highlight Spanish-speaking students' knowledge through their native language often became over-shadowed by the white, English-speaking students' advanced academic abilities. This outcome manifested in a variety of public ways, including English-dominant students' higher reading levels (in both English and Spanish), which often became evident in their reading fluency skills, their ability to complete their work quickly, often before Latino students, and their ability to outscore their Spanish-speaking peers on standardized tests.

Ironically, the placement strategies create a situation where Latina/o students are constructed as deficient even though they are in a classroom that was designed and implemented in order to highlight their linguistic and cultural competencies. Mr. Potts discusses the challenge of teaching such a wide range of students and how, despite his intentions, he feels he is doing a disservice to many of the Latino students in his class.

And yeah, then you go, 'maybe you're not hitting all the kids' reading levels. You should have them reading books that range from K-6.' But then you also have little kids that I'm going, OK, if I do that, where does that put Mario? Where does that put Cassandra? Where does that put Fernando? Kids that got geared into my track, not by parental choice, but by teachers bringing in kids that couldn't succeed anywhere else. Suddenly David and Sarah and Brian read 


\begin{abstract}
higher than them in Spanish and English. So, what have I done? When they were in another classroom, and they had to go to another group in the corner, it was 'oh, it's because they're Spanish speakers.' That their language is an excuse. Now I've stripped them of their excuse. They're low in both. The English kid can out do them in both environments. And then I go, 'I've done them a disservice.' It's a disservice, because though the excuse was a lie, I let them hold face. They had the excuse that 'the reason that I'm not doing well, is because I'm having to learn another language.' And now they don't have that, because David or Sarah or Brian or Adam can say, 'so are we, and we can read your language better than you can.' And it makes it really tough.
\end{abstract}

In this interview, Mr. Potts contemplates whether he truly serves the Latina/o, Spanish-speakers better in his class or if they would fare better in a mainstream classroom where their status of being a language learner can mask some of the other issues that serve as barriers to their education, namely, racism and poverty.

Mr. Potts' intentions in implementing a dual language classroom was to provide an equitable schooling experience for Latina/o, Spanish-speaking students. In Mr. Potts' mind, the dual language approach was ideal because it not only allowed him to build upon the cultural and linguistic resources that his Latina/o students brought to his classroom, but it positioned bilingualism as an ideal worthy of all students achieving. In many ways, Mr. Potts met these goals (e.g., all students in his class valued and perceived Spanish as an academic language and were working toward the goal of bilingualism), which was a significant transformation from the assimilationist, English-only classes other Latina/o students were attending within the school. At the same time, however, his goals for equitable educational experiences were constrained by the placement strategies that were being utilized within his specific schooling context. In continuation with this theme on the (im)possibilities of critical care, I now turn to data that focuses on Mr. Potts' attempts to submit his students' written work to poem contests.

\title{
Poem Submissions
}

In Mr. Potts' attempts to critically care, he not only goes against the grain, such as when he implements the dual language model in his classroom, but he also goes against the rules of the game in order to carve out potentially caring pedagogies that highlight his students' knowledge. As Valenzuela (1999) puts it, "The inflexibility of bureaucracies often places caregivers in the problematic position of having to break rules in order to be caring" (p. 81). In this example, Mr. Potts submitted his Latina/o, Spanish-speaking students' poems to a number of poetry contests that were intended for English language submissions only. Nowhere in the rules and regulations of the contest was it written that poems needed to be submitted in a particular language. However, given the normative 
status of the English language in the U.S., no mention of language can be assumed to mean English only. Mr. Potts challenged the vagueness of the rules and their implicit meaning by submitting the poems his Latina/o, Spanishdominant students wrote in Spanish, along with the poems being submitted by his white, English-dominant students, written in English. While Mr. Potts' intention in submitting his students' poems in their native languages was to have them evaluated and bring attention to the truly outstanding poems that were being written in both languages, the outcomes of his poem submissions were less than desired. Mr. Potts explains the results of this practice in an interview:

The students who wrote in English received response letters and the children who wrote in Spanish didn't receive any recognition whatsoever. Not even a response that theirs had been sent, which bothered me immensely, because I went back to the rules and there was nothing that said that it had to be wrote in English. With another contest, which is right in the school, I called Washington D.C. and asked the National PTA for the rules, what had to be done; 'cause I already had this one bad experience and they said that entering it in Spanish is just fine, but that I needed to go through and mark all of the mistakes in red, which, first of all, makes the Hispanic child's paper look worse than the Anglo child's paper, which I didn't like, and then provide a close-as-possible wordfor-word translation at the bottom that would still convey the meaning. And in poetry word-for-word really stinks, but I did my best. And, uh, last year's contest they were thrown away. Uh, the judge at the school had assumed that the words used by the Spanish-speaking students were too high of a level. Uh, an example is the word 'subterraneo' which means underground. And the close cognate I could come up with was subterranean and she was just positive that no fourth or fifth grade child would use the word subterranean. And so, they just threw away all of my students' entries. So the following year I did not mass encourage my class. The first year every single child in my class entered. The second year I just went through, and those kids who had some beautiful poetry on their own throughout the year, I said don't you want to enter this? And so, uh, Leticia, hers was the only one in Spanish entered. So it [Spanish entries] went from half the class to one. And when I translated it I took it to two other teachers that both were Spanish speakers and had them verify and write on a note that it was translated and that this was their original work. I never made a comment to the judges or the people in the PTA that I had went and done that, but hers was not only one of the winners in the school level, but it was the only one.

Despite Mr. Potts' critical care orientation, the system largely prevailed in not granting access to Mr. Potts' Latina/o, Spanish-dominant students. As shown in this example, Mr. Potts' attempts to bring recognition to his Latina/o students' work in Spanish was constrained by the assimilationist context in which he works. In the end, Mr. Potts' persistence pays off in the sense that he pushed the 
poem committee to come up with a process in which they could evaluate poems in Spanish, which ultimately brought recognition to one Latina student's work.

\section{Mr. Potts Votes No: A Critical Care Perspective in a Vote Against Bilingual Education}

As this case study continues to demonstrate, the politics of caring are rarely straightforward. This finding became especially apparent when the school district received a grant to implement a school-wide dual language immersion bilingual program at Viewpoint Elementary as well as several other elementary schools within the district. In interviews and informal conversations, Mr. Potts explained that the teachers at Viewpoint Elementary were openly opposed to and even hostile towards the idea of implementing a school-wide dual language immersion program. One of the primary reasons Mr. Potts cited as to why teachers did not support the idea of implementing a dual language immersion bilingual program was because it would mean that they would have to teach Latino, Spanish speakers during the portion of the day they would receive English instruction, instead of referring them out of their classes for language services - the option that other language programs (e.g., ESL and Transitional Bilingual) allow.

When it came time for teachers to vote on whether the dual language bilingual program should be implemented school-wide at Viewpoint Elementary, and after carefully considering the position the teachers were taking on this issue, Mr. Potts strategically decided to vote against the implementation of the program at Viewpoint Elementary. Paradoxically, in his efforts to build a supportive context for his Latino, Spanish-dominant students, and despite his own personal and professional support for bilingual education, Mr. Potts strategically sided with teachers who fought the implementation of bilingual education at his school. Because he felt that it was vital to avoid further hostility between anti-bilingual education teachers and the linguistic minority students and their parents, and because he did not believe that a bilingual program would succeed without the support of the school as a whole, he thought his efforts would be better spent supporting the teaching staff in their decision to not implement the bilingual program. Thus, rather than fight a lone, heroic, but ultimately counter-productive battle by trying to force school-wide implementation of bilingual education on unwilling and resentful teachers, Mr. Potts ultimately voted against the bilingual program, quit his teaching position at Viewpoint Elementary, and sought out a position at an elementary school within the district that did accept the dual language grant and where he would be part of a network of pro-bilingual teachers. 
A vote against bilingual education, on the surface level, does not seem to represent a critical care perspective. In fact, a vote against bilingual education seemingly supports an aesthetic approach to caring - an approach that reinforces an assimilationist viewpoint that places little to no value on students' already established linguistic and literacy development. However, further examination of Mr. Potts' vote against bilingual education reveals that Mr. Potts simply admitted defeat within this schooling context. That is-he came to the realization that his critical care perspective and practices were often of little significance in a larger schooling context that pushed an assimilationist and deficit-oriented perspective. In the end, when Mr. Potts decided he could no longer work at this school, he did not give up on the teaching profession altogether, as many teachers do, but rather he decided to support the teachers who would be staying behind to teach Viewpoint Elementary students.

\section{Conclusion}

The purpose of this article is not to discredit or otherwise discourage critical care pedagogies. On the contrary, critical approaches to caring are essential to the goal of providing culturally appropriate and equitable educational opportunities to Latina/o students. Thus, the purpose of this article is to fully support and encourage a critical care perspective, yet provide a realistic appraisal of what critical care practices might look like in assimilationist school settings. By characterizing critical care by its (im)possibilities, I argue that in the same way praxis and activism should not be defined only in terms of grand, romanticized notions of bringing about change (Urrieta, 2009), critical care should not be overly idealized.

This perspective is crucial in a teaching profession where one-third of new teachers quit the profession within their first five years of being in the classroom (Democracy At Risk, 2008). Their desire-their motivation for becoming a teacher - is likely bound to the idea of really making a difference in students' lives. When this difference does not seem to happen at the magnitude they imagined, their seeming failure may come to reflect on their own capacity and value as a teacher (Britzman, 2003), rather than on the institutional and social forces their pedagogical practices are embedded in. At the very beginning of this article, we saw the outcomes of Mr. Potts' critical care practices bound to his own self-appraisal of himself as an ineffective teacher. In hopes of moving the teaching profession towards a more critical approach to caring as well as discouraging teachers from giving up on a critical care perspective, and possibly the teaching profession altogether, this article provides a brief glimpse of critical care practices that are by no means ideal, but important and transformative nonetheless. 


\section{References}

Antrop-González, \& De Jesús, A. (2006). Toward a theory of critical care in urban small school reform: Examining structures and pedagogies of caring in two Latino community-based schools. International Journal of Qualitative Studies in Education, 19(4), 409-433.

Britzman, D.B. (2003). Practice makes practice: A critical study of learning to teach. New York: SUNY.

De Jesús, A., \& Antrop-González, R. (2006). Instrumental relationships and high expectations: Exploring critical care in two Latino community-based schools. Intercultural Education, 17(3), 281-299.

Democracy at risk: The need for a new federal policy. (2008). Washington DC: The Forum for Education and Democracy.

Nieto, S. (2008). Nice is not enough. In M. Pollock (ed.), Everyday antiracism: Getting real about race in school. New York: New Press

O'Connor, C. (1997). Dispositions toward (collective) struggle and educational resilience in the inner city: A case analysis of six African-American high school students. American Educational Research Journal, 34, 593-629.

Rolón-Dow, R. (2005). Critical care: A color(full) analysis of care narratives in the schooling experiences of Puerto Rican girls. American Educational Research Journal, 4(1), 77-111.

Strauss, A.L. (1996). Qualitative analysis for social scientists. New York: Cambridge University Press.

Thompson, A. (1998). Not the color purple: Black feminist lessons for educational caring. Harvard Educational Review, 68(4), 522-554.

Urrieta, L. (2009). Working from within: Chicana and Chicano activist educators in Whitestream schools. Tucson: The University of Arizona Press.

Valenzuela, A. (1999). Subtractive schooling: U.S.-Mexican youth and the politics of caring. Albany, NY: State University of New York Press. 